(if I have correctly translated the passage); and Decianus Kalus (the Superintendent of the island) asserted that

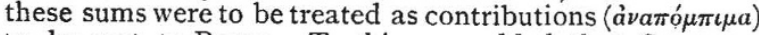
to be sent to Rome. To this was added that Senecawho was not only philosopher, poet, and Minister of State,

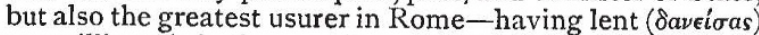

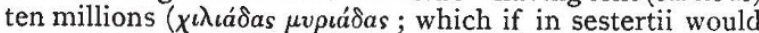

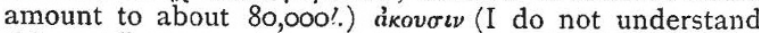
this word) on sound hopes of interest, suddenly, and with violence, exacted the return of the whole; that it was Boadicea (Voo-doo-ee-ka) who principally caused the rising of the Britons. In the usual history of this lady there is much to be corrected. She was not Queen of the Iceni, though of the royal family ( ćvovs $^{\prime}$ rov $\beta a \sigma i \lambda \epsilon i o v$ ). She had no husband or children. There is not the slightest allusion to any personal insult. She did not die in battle, but died from disease $(\nu o ́ \sigma \omega)$ after the battle.

Boadicea, as Dion remarks, was greater than woman. She collected the army of about 120,000 men. She mounted a $\beta \hat{\eta} \mu a$, made in the Roman fashion, to raise her from the mud. She was tall in person, very awful in countenance, with keen eyes and a rough voice; her abundance of yellow hair fell far down her body; she had chain-armour of gold, a variegated vest, and a thick cloak.

A very long speech is given, of which the following are the principal heads :-The superiority of liberty to slavery ; the criminal character of the taxes, some even levied from the dead; the Britons themselves are the cause of these evils, not having resisted them soon enough; the habits of our enemies expose them to far greater difficulties than those which we endure ; and other remarks, finishing with a kind of enchantment over a hare.

The Britons proceeded to terrible and savage excesses, the worse because Plautius was absent, having gone to M $\hat{\omega} \nu \nu \alpha$; which, if it be the same as the Móva of Ptolemy, is the Isle of Anglesey. But this appears to me to be, etymologically, very doubtful; and, practically, I think it very improbable that, in such a state of affairs, Plautius would have gone, by a difficult march, to such a distance. Plautius however returned, and a battle soon took place.

There is no difficulty in fixing on the site of this, one of the great battles of history. In the neighbourhood of Linton, at the north boundary of Essex, in a space perhaps of two square miles, are places which still bear the names of Shudy Camps, Castle Camps, Camp's End, Camp's Green, Camp's Castle. Every one of these has undoubtedly been the scene of a desperate struggle. And, finally, there are the three mighty mounds, known as the Bartlow Tumps, which, as I understand, have been identified as containing Roman remains.

Dion has given a long account of the various phases of the battle. Boadicea died of illness ( $\left.\nu^{\prime} \sigma \omega\right)$, and the Britons were driven off the field. The battle was sufficiently decisive to prevent the re-appearance of the Britons in force ; but still it appears, I think, not to have made a complete conquest.

-The news was welcomed at Rome with very great interest by the Emperor, the Senate, and every rank of society.

G. B. AIRY

\section{THE EUROPEAN PREHISTORIC RACES}

$\mathrm{I}^{\mathrm{T}}$ would be difficult to overrate the scientific value of the discovery of human remains made last summer in Belgium, and briefly noticed in NATURE of February 24 (p. 405). Hitherto serious doubts have prevailed regarding the true character of the Canstadt, Neanderthal, Eguisheim, Olmo, and four or five other skulls, which are collectively referred to the oldest known race in Europe, but which, owing to their apparently exaggerated simian features, have been loo'sed on with suspicion by Pruner, Virchow, and others, as possibly exceptional or even mere pathological specimens. But these doubts have at last been set at rest by the lucky find made last June by MM. Max Lohest and Marcel de Puydt, who, during their explorations of a cave on the slope of a wooded hill on the banks of the Orneau, in the commune of Spy, province of Namur, came upon numerous remains of two individuals amid hitherto undisturbed Lower Quaternary deposits, and in association with the bones of Rhinoceros tichorinus, Elephas primigenius, Ursus spelceus, Hyana spelcea, Felis spelaa, the horse, wolf, sheep, and other now extinct and surviving Pleistocene animals. These remains have been carefully examined by M. Julien Fraipont, Professor of Animal Palæontology in the University of Liege, who unhesitatingly refers them to the Palæolithic race, to which King's expression "Homa neanderthalensis" may now be confidently applied. Taken especially in combination with the peculiarities of other parts of the skeleton, such as the evidently angular position of femur and tibia, implying a non-erect or stooping attitude in standing or walking, the skulls of the two Spy men show clearly that those of the Canstadt and Neanderthal men are in no way aberrant, but perfectly normal specimens. They obviously represent a Palæolithic and pre-Glacial race, the earliest of which there is any distinct record, which was already spread over West Central Europe in early Quaternary times, and which De Quatrefages and Dr. Hamy now believe may uitimately be traced back to the later Tertiary epoch.

A far better idea of the physical characteristics of the Homo neanderthalensis can be had from the remains of the Spy men, than from any others hitherto brought to light. Prof. Fraipont, who devotes a lengthy memoir to the subject in the Bulletin of the Royal Belgian Academy for December, gives detailed osteological descriptions of the two more or less perfect skeletons, from which it appears that of one there are extant: the skull, relatively very complete; the right portion of the upper jaw, with five molars; a fragment of the left portion, with the two premolars, incisor and canine; the under jaw, nearly complete, with sixteen intact teeth in situ; a left clavicle; the right humerus, less the upper epiphysis; the left humerus, less both epiphyses; the left radius; the right femur, nearly complete ; the left femur, complete; the left tibia, complete; the right heel. Several of the parts here missing are supplied by the second skeleton; and there are also numerous vertebræ, fragments of ribs, \&c., which cannot with certainty be referred to one rather than the other.

The first skull (No. I) includes: the frontal bone from the superciliary arches and naso-frontal suture to the parieto-frontal suture ; the right parietal, nearly complete ; the upper half of the left parietal; the occipital, less a considerable portion of the region of the cerebellum. Of the second skull (No. 2) there remain : the frontal, very nearly complete ; the right and left parietals, complete all but a few fragments of the former: the right temporal, nearly complete; the left temporal, complete; the occipital, less a portion of the region of the cerebellum.

The first is very long, very depressed from above, and narrow, being decidedly platidolichocephalic, with cephalic index 70 , as compared with 72 of the Neanderthal skull, and 67.65 of the Clichy. The second is subplatidolichocephalic, with apparent index $74: 80$, and general characters less pronounced than those of No. I, but not to such a degree as to prevent the two from being referred to the same race. Of both, the longest anteroposterior diameter is about the same, 200 and 198 to $200 \mathrm{~mm}$. respectively, the former corresponding exactly with the Neanderthal. But the transverse differs considerably, being I 40 and I 50 , between which comes the Neanderthal with $144 \mathrm{~mm}$. On the other hand, the antero-posterior frontal curve of the first coincides exactly with that of the Neanderthal, the frontal itself being, like it, low and retreating. Another typical feature of this 
frontal is the great development of the superciliary arches, although slightly less prominent than those of the Neanderthal and Eguisheim. The distance between their outer extremities is no less than $122 \mathrm{~mm}$., while the arches converge at the very root of the nose, leaving a slightly depressed intervening glabellar region, this region differing perceptibly from that of the Neanderthal, in which the glabella is prominent.

Although otherwise well preserved, the under jaw of No. I unfortunately lacks the condyles, which would have enabled us to settle the important question of its relative prognathism. This jaw is very high and massive, and the well-preserved teeth of both present the general characters found amongst the New Caledonians and other modern races of low type. The canines and incisors of the under jaw are worn obliquely and outwardly, those of the upper jaw obliquely and inwardly, although in general to a less extent than amongst the Neolithic races.

The right femur of No. I is not large, but very strong and heavy, and is specially remarkable for its typical forward curvature. The great posterior development of the articular surface of its condyles, taken in connection with the general curvature of the body, shows that the Spy men walked with the knees bent forward, the thigh being obliquely curved forward and downward, and the leg reversed backwards. In other words, the femur was adjusted obliquely to the tibia, which was itself strong, thick and heavy, but very short.

The discoveries at Spy are specially valuable because found associated with other remains which enable us to determine approximately the epoch of analogous finds elsewhere. The already mentioned fauna, as well as the character of the coarse flints occurring in the same undisturbed strata, would seem to indicate that both the Spy men, and their Canstadt and Neanderthal congeners, must have flourished in the époque Moustierienne of French writers, that is, during the early period of the mammoth, and long before the beginning of the Reindeer Age. They were consequently more recent than the race of the epoque Cheliéenne, which was contemporary with Elephas antiques, but of which no actual remains, beyond the objects of its industry, have yet been discovered. That they belonged in any case to pre-Glacial times seems evident from the remarkable absenc of the eindeer, which is not numerously met in West and Central Europe till the Ice period.

M. Fraipont's comparative study of these remains makes it thus abundantly evident that they belong to the Neanderthal type. The two skulls even serve as a sort of missing link between the Neanderthal and the others usually referred to the same race. This race, whose presence in Europe during the early Mammoth Age has now been clearly traced from Stængenæs in Scandinavia to Olmo in Italy, seems in a way to have been resuscitated by the fortunate discovery in the limestone cave on the banks of the Orneau. Their dry bones again assume flesh and blood, and science is enabled confidently to describe the men of Spy as a short, but far from "feeble folk," thick-set, robust, walking knees foremost, and with a figure somewhat analogous to that of the modern Lapps, who also still waddle and are nearly all more or less bandy-legged. Their broad shoulders supported a long, narrow, and depressed head (different therefore from that of the true Papuan, which is long, narrow, and high), with very prominent superciliary arches, enormous orbits; low and retreating brow, high and massive cheek-bones, receding chin. No modern race, however low in the scale of humanity, is collectively characterised by all these traits, so that it may be safely affirmed that the ethnical type of the men of the Mammoth Age has become practically extinct, either through further evolution within itself, or by extirpation, or more probably by fusion with men of a higher physical standard.

It is noteworthy that the points which most separate the men of Spy from the present inhabitants of the globe are precisely those which bring them into closer relation with the anthropoid apes in general, rather than with any particular species of anthropoids. These points, which may thus fairly be described as pithecoid or simian, are chiefly: the prominent superciliary arches, normal in the young male gorilla and adult female orang; the extremely low retreating frontal, constant in the chimpanzee of both sexes and all ages; the almost chinless receding lower jaw, highly typical of gorilla and chimpanzee; lastly, the peculiar curvature of the femur, combined with its adjustment to the tibia, suggesting in the vertical position an attitude somewhat analogous to that of chimpanzee and gorilla. On the other hand, all the other features of cranium, trunk, and limbs are distinctly human, while the cranial capacity alone would suffice to justify the claim of Homo neanderthalensis to membership with the human rather than with the simian family. However great the distance separating him even from the lowest of modern races, far greater, undoubtedly, is the interval between him and the highest of the modern anthropoids. At the same time this interval becomes perceptibly diminished by Gaudry's discovery of Dryopithecus fontanii, an anthropoid ape of the middle Miocene epoch certainly less simian, or rather more human, than any of its present congeners. Its lower jaw is perceptibly less receding than that either of the gorilla, orang, or chimpanzee. The interval tends to be still further reduced when we remember that, although the Homo neanderthalensis is the earliest human type of which any bodily remains have hitherto been discovered, there is a still more primitive race revealed to us by the rude palæolithic implements frequently occurring in association with Elephas antiquus, and in later Tertiary deposits considerably older than the Lower Quaternary of the Spy cave. Whenever any characteristic remains of this primæval race come to light, a distinct approach will have been made towards a solution of the difficult questions connected with the genetic descent of mankind.

A. H. KEANE

\section{AN EXAMINATION OF THE LEAVES OF GYMNEMA SYLVESTRE ${ }^{1}$}

GYMNEMA SYLVESTRE (R. Br.) is an asclepiadaceous plant growing in the Deccan peninsula, from Concan to Travancore ; it is also met with in Assam, and on the Coromandel coast, and is distributed in the continent of Africa. It is a stout woody climber, with long slender branches.

The leaves are opposite, entire, from $\mathrm{I} \frac{1}{2}$ to 3 inches long, and from $I$ to 2 inches broad, elliptic or obovate, acute or cuspidate, rarely cordate at the base, membranous, thinly pubescent on both sides, the upper surface of a darker green than the lower. Gymnema sylvestre is mentioned in the non-official list in the Pharmacopœia of India (1868), and in Dr. Dymock's "Materia Medica of Western India." The powdered root has for a long time been known among the Hindus as a remedy for snake-bites; in such cases it is applied locally to the part affected, and also taken internally in the form of a decoction. But the most curious circumstance connected with this plant was first noticed by Mr. Edgeworth, who discovered that by chewing some of the leaves it destroyed the power of the tongue to appreciate the taste of sugar; he found that powdered sugar, taken immediately after masticating some of the leaves, tasted like so much sand in his mouth, and this effect lasted for twenty-four hours. Dr. Dymock, reviewing this property, said he was unable entirely to confirm this statement; his experience was that sugar taken into the mouth after chewing the fresh plant had a saltish taste, but was still easily recognisable.

I A paper read at a meeting of the Nilgiri Natural History Society Ootacamund, by David Hooper, F.C.S., March $7,{ }^{8} 887$. 